\title{
Bovine Testicular $\beta$-Galactosidase: Purification of Enzyme Fractions That Exhibit High Affinity for Phosphomannosyl Receptors ${ }^{1}$
}

\author{
Jack J. Distler, Jinfeng Guo, G. Gary Sahagian, ${ }^{2}$ and George W. Jourdian ${ }^{3}$ \\ Rackham Arthritis Research Unit and the Departments of Biological Chemistry and Internal Medicine, \\ The University of Michigan Medical School, Ann Arbor, Michigan 48109
}

Received April 14, 1989

An improved method is described for the preparation of bovine testicular $\beta$-galactosidase that allows the isolation of enzyme fractions that bind avidly to phosphomannosyl receptors. The procedure permits removal of a contaminating $\beta$-hexosaminidase and yields nearly homogeneous $\beta$-galactosidase. Enzyme eluted from DEAE-Sephacel was arbitrarily divided into pools that exhibited differing ability to bind phosphomannosyl receptors. A high binding fraction was rapidly assimilated by cultured cells and bound to both low and high molecular weight phosphomannosyl receptors. Carbohydrate analysis of the high binding fraction indicates an average content of one complex and one high mannose oligosaccharide chain per molecule and an average mannose 6-phosphate content of two residues per molecule. However, electrofocusing studies indicated that all the fractions were heterogeneous with respect to sialic acid and phosphate content. The purification procedure also provides highly purified $\beta$-galactosidase suitable for removing $\beta$-galactosidase residues from a variety of complex carbohydrates. 1989 Academic Press, Inc.

Bovine testicular $\beta$-galactosidase, a lysosomal hydrolase, was previously purified by affinity chromatography on phenylthio- $\beta$-galactoside-substituted agarose and

\footnotetext{
${ }^{1}$ This work was supported in part by Grant AM-10531 from the National Institutes of Arthritis, Metabolism, and Digestive Diseases and in part by the Arthritis Foundation, Michigan Chapter.

${ }^{2}$ Supported in part by Training Grant AM-5026 from the U.S. Public Health Service and a predoctoral fellowship from the Horace $\mathrm{H}$. Rackham School of Graduate Studies, University of Michigan. Present address: Department of Physiology, Tufts University, Boston, MA.

${ }^{3}$ To whom correspondence should be addressed: R4633 Kresge Medical Research I, University of Michigan, Ann Arbor, MI 48109.
}

shown to catalyze the hydrolysis of terminal $\beta 1,3-, \beta 1,4-$, and $\beta 1,6$-linked galactosyl residues from a variety of oligosaccharides, glycoproteins, and glycolipids $(1,2)$. The enzyme binds to the surface of cultured cells and is rapidly assimilated (3). The internalization process is mediated by membrane-bound phosphomannosyl receptors which specifically recognize mannose 6-phosphate contained in oligosaccharide chains of the enzyme (4). Purified $\beta$-galactosidase was utilized as a model ligand for the isolation, measurement, and characterization of high and low molecular weight forms of phosphomannosyl receptors $(5,6)$.

The present manuscript describes (i) a simplified method for the purification of $\beta$-galactosidase that incorporates absorption of the enzyme to concanavalin Aagarose and ion-exchange chromatography on DEAESephacel and (ii) the partial characterization of enzyme subfractions that exhibit differential binding to high and low molecular weight phosphomannosyl receptors. The methodology yields enzyme fractions that are free of catalytically active $\beta$-hexosaminidase and neuraminidase, enzymes reported to contaminate affinity-purified $\beta$-galactosidase preparations $(1,2,7)$. A preliminary report has been presented (8).

\section{MATERIALS AND METHODS}

Concanavalin A-agarose, DEAE-Sephacel, Escherichia coli alkaline phosphatase, $p$-nitrophenyl derivatives of $\beta$-galactopyranoside, ${ }^{4} N$-acetyl- $\beta$-glucosaminide, $2^{\prime}$ - (4 - methylumbelliferyl) - $\alpha-N$ - acetylneuraminic acid, methyl- $\alpha$-mannopyranoside, 5-bromo-4-chloro-3indolyl- $\beta$-galactopyranoside, and mannose 6-phosphate

\footnotetext{
${ }^{4}$ Unless otherwise described, all monosaccharides are of the D configuration.
} 
were obtained from Sigma. $N$-Glycanase was obtained from Genzyme. Sodium boro- $\left[{ }^{3} \mathrm{H}\right]$ hydride (sp act 409 $\mathrm{mCi} / \mathrm{mmol}$ ) was obtained from Amersham. Bovine high molecular weight phosphomannosyl receptor (PMR-1) (9) and low molecular weight phosphomannosyl receptor (PMR-2) (6) were prepared as previously described.

Polyacrylamide gel electrophoresis was conducted in $9 \%$ polyacrylamide gels under reducing conditions as described by Laemmli (10). Proteins were stained with Coomassie blue.

Isoelectric focusing was performed in a Bio-Rad Model III IEF Cell on $5 \%$ polyacrylamide slab gels containing $2 \%$ Pharmalyte ( $\mathrm{pH} 4-6.5)$ and $5 \%$ glycerol. The gels were cast on Gel Support Film (Bio-Rad) and, after application of samples, voltages of $100,200,450$, and 950 $\mathrm{V}$ were sequentially applied for $1 \mathrm{~h}$ each. Gels were stained for $\beta$-galactosidase activity using 5-bromo-4chloro-3-indoyl- $\beta$-galactopyranoside at $\mathrm{pH} 4.3$ (11).

Neutral sugars and hexosamines were estimated by gas/liquid chromatography as their glycitol acetate derivatives (12). Glycoprotein-bound mannose 6-phosphate was determined after Dowex 50-catalyzed hydrolysis (3). Sialic acid content was determined by the procedure of Takasaki and Kobata after prior hydrolysis in $0.01 \mathrm{~N} \mathrm{HCl}$ at $100^{\circ} \mathrm{C}$ for $30 \mathrm{~min}$ (13). In each case the charged monosaccharide sugars were reduced with $\mathrm{NaB}^{3} \mathrm{H}$ and separated by paper electrophoresis; the migration of the ${ }^{3} \mathrm{H}$-labeled carbohydrates was compared to that of standard saccharides treated in the same manner. Amino acid analyses were kindly performed by the late Dr. D. Dziewiatkowski, University of Michigan Dental School. Samples were hydrolyzed at $100^{\circ} \mathrm{C}$ in $6 \mathrm{~N}$ $\mathrm{HCl}$ for $24 \mathrm{~h}$, oxidized by exposure to air in $0.05 \mathrm{M}$ sodium phosphate at $\mathrm{pH} 7.0$ for $24 \mathrm{~h}$, and quantitated on a Beckman Model $121 \mathrm{M}$ amino acid analyzer.

Assimilation of $\beta$-galactosidase by skin fibroblasts from generalized gangliosidosis patients (13) and binding of $\beta$-galactosidase to PMR-1 and PMR-2 immobilized in multiwell plates (14) were performed and corrected for nonspecific binding as previously described. Protein was determined by the procedure of Lowry et al. (15). Assays of $\beta$-galactosidase, $\beta$ - $N$-acetylhexosaminidase $(1)$, and neuraminidase $(7,16)$ were performed as described.

\section{Preparation of Bovine Testicular $\beta$-Galactosidase}

Unless otherwise noted, all steps were carried out at $4^{\circ} \mathrm{C}$. One unit of $\beta$-galactosidase is defined as that amount of enzyme that hydrolyzes $1 \mu \mathrm{mol}$ of $p$-nitrophenyl- $\beta$-galactopyranoside in $1 \mathrm{~min}$.

\footnotetext{
${ }^{5}$ Abbreviations used: PMR-1, high molecular weight phosphomannosyl receptor; PMR-2, low molecular weight phosphomannosyl receptor; W, column wash; VL, very low binding; L, low binding; $H$, high binding; VH, very high binding; SDS-PAGE, sodium dodecyl sulfatepolyacrylamide gel electrophoresis.
}

Step 1. The enzyme was prepared by modification of a previously described procedure $(1,2)$. Decapsulated tissue (six testes, $1600 \mathrm{~g}$ ) was cut into pieces approximately $1 \mathrm{~cm}^{3}$ and homogenized in a Waring blender for $2 \mathrm{~min}$ in $1600 \mathrm{ml}$ of a solution comprised of $0.1 \mathrm{~N}$ acetic acid and $0.1 \mathrm{M} \mathrm{NaH} \mathrm{PO}_{4}$. The homogenate was centrifuged at $10,000 \mathrm{~g}$ and the precipitate discarded; the crude supernatant $(1400 \mathrm{ml})$ contained 249 units $\beta$-galactosidase (sp act $0.015 \mathrm{unit} / \mathrm{mg}$ protein).

Step 2. Solid ammonium sulfate was added with stirring to $75 \%$ saturation. After stirring for $30 \mathrm{~min}$, the precipitate was collected by centrifugation for $20 \mathrm{~min}$ at $10,000 \mathrm{~g}$. The pellet was suspended in $400 \mathrm{ml}$ of a solution comprised of $0.05 \mathrm{M}$ Tris-HCl, $\mathrm{pH} 7.5$, and $0.15 \mathrm{M} \mathrm{NaCl}$. A small amount of particulate material was removed by centrifugation. The supernatant $(400 \mathrm{ml})$ contained 247 units $\beta$-galactosidase (sp act $0.016 \mathrm{unit} / \mathrm{mg}$ protein).

Step 3. The supernatant solution was adjusted to $\mathrm{pH}$ 7.5 with $0.5 \mathrm{M}$ Tris and applied to a $4 \times 10-\mathrm{cm}$ column of concanavalin A-agarose previously equilibrated with $0.05 \mathrm{M}$ Tris- $\mathrm{HCl}, \mathrm{pH} 7.5$, containing $0.15 \mathrm{M} \mathrm{NaCl}$. The column was washed rapidly at room temperature with 2 liters of $0.05 \mathrm{M}$ Tris $-0.15 \mathrm{M} \mathrm{NaCl}, \mathrm{pH} 7.5$, and the $\beta$ galactosidase eluted from the column at room temperature with $400 \mathrm{ml}$ of the same buffer containing $0.75 \mathrm{M}$ methyl- $\alpha$-mannopyranoside. The eluant $(400 \mathrm{ml})$ contained 177 units $\beta$-galactosidase (sp act 0.19 unit $/ \mathrm{mg}$ protein).

Step 4. The column eluant was adjusted to $\mathrm{pH} 5.0$ with $4 \mathrm{~N}$ acetic acid and subjected to a single cycle of affinity chromatography on a $4 \times 10-\mathrm{cm}$ column of phenylthio- $\beta$-galactoside-substituted agarose as previously described (2). Enzyme was eluted with $750 \mathrm{ml} 0.05 \mathrm{~N}$ Tris- $\mathrm{HCl}, \mathrm{pH} 7.5$; the eluant contained 106 units $\beta$-galactosidase (sp act 5.4 units/mg protein).

Step 5 . The eluant from the affinity matrix containing approximately 100 units of $\beta$-galactosidase was concentrated to a volume of $50 \mathrm{ml}$ by pressure filtration over an Amicon YM 10 filter (Amicon Corp.) and dialyzed for $18 \mathrm{~h}$ against $20 \mathrm{vol}$ of $0.05 \mathrm{M}$ Tris- $\mathrm{HCl}, \mathrm{pH} 7.5$. The dialyzed solution was clarified by centrifugation $(10,000 \mathrm{~g})$ and applied to a $2 \times 15-\mathrm{cm}$ column of DEAESephacel previously equilibrated with $0.05 \mathrm{M}$ Tris- $\mathrm{HCl}$, $\mathrm{pH}$ 7.5. The column was washed with $100 \mathrm{ml}$ of buffer and $\beta$-galactosidase eluted with a linear gradient that consisted of $400 \mathrm{ml}$ of the Tris buffer in the mixing chamber and $400 \mathrm{ml}$ of the same buffer containing $0.2 \mathrm{M}$ $\mathrm{NaCl}$ in the reservoir; $12-\mathrm{ml}$ fractions were collected. The major portion of $\beta$-galactosidase appeared as a broad peak that eluted between 100 and $500 \mathrm{ml}$ of the gradient buffer.

\section{Isolation of $\beta$-Galactosidase Receptor Binding Pools}

Fractions from Step 5 containing enzyme were pooled in such a fashion that approximately $10 \%$ of the total 
enzyme activity appeared in the most anionic and least anionic protein fractions. The intermediate fractions were divided into two approximately equal pools each containing approximately $40 \%$ of the total enzyme activity (Fig. 1). Each enzyme fraction was concentrated to a final volume of $2-5 \mathrm{ml}$ by pressure filtration as described under Step 5. Sodium azide was added to a final concentration of $0.02 \%$. The purified enzyme retained activity and receptor binding properties for at least 6 months when stored at $0-5^{\circ} \mathrm{C}$.

\section{RESULTS}

Bovine testicular $\beta$-galactosidase was purified 400 fold in $43 \%$ yield from the crude testes supernatant by a procedure described under Materials and Methods employing $\left(\mathrm{NH}_{4}\right)_{2} \mathrm{SO}_{4}$ precipitation, elution from concanavalin- $A$ agarose, and affinity chromatography on phenylthio- $\beta$-galactoside-substituted agarose. Chromatography on concanavalin A-agarose prior to affinity chromatography allowed maximal purification of $\beta$-galactosidase by a single cycle of affinity chromatography. In our initial description of the purification of testicular $\beta$-galactosidase, which lacked the conanavalin A-agarose step, two affinity chromatography cycles were necessary to remove contaminating proteins that precipitated on the affinity matrix during the first passage through the column (2). Precipitation in the matrix was not observed in the present procedure.

Neuraminidase, reported to copurify with $\beta$-galactosidase (7) was not detected in the present preparation after Step $2\left[\left(\mathrm{NH}_{4}\right)_{2} \mathrm{SO}_{4}\right.$ precipitation]. However, neuraminidase (2-4 units) was found in the residue that remained after resuspension of the $\left(\mathrm{NH}_{4}\right)_{2} \mathrm{SO}_{4}$ precipitate.

Formerly, even the most highly purified $\beta$-galactosidase preparations contained $\beta-N$-acetylhexosaminidase activity which bound independently to the affinity matrix (1). The $\beta$ - $N$-acetylhexosaminidase was resolved from $\beta$-galactosidase by chromatography on DEAESephacel using a linear gradient of increasing $\mathrm{NaCl}$ concentration (Fig. 1). The ion-exchange column fractions containing $\beta$-galactosidase were pooled into fractions that differed in their capacity to bind phosphomannosyl receptors as shown in Fig. 1. Cell assimilation and receptor binding characteristics of the pooled fractions are described in Table 1. Those fractions that bound more strongly to DEAE-Sephacel exhibited enhanced uptake by cultured cells and bound more avidly to both high and low molecular weight phosphomannosyl receptors. Although the binding spectrum of the $\beta$-galactosidase fractions appeared to be similar for the two phosphomannosyl receptors, the affinity of each fraction for PMR-2 was lower than that for PMR-1. For example, the $K_{D}$ values found for PMR-1 and PMR-2 were 10.2 munit $/ \mathrm{ml}$ and $110 \mathrm{munit} / \mathrm{ml}$, respectively, for fraction $\mathrm{H}$. Uptake of

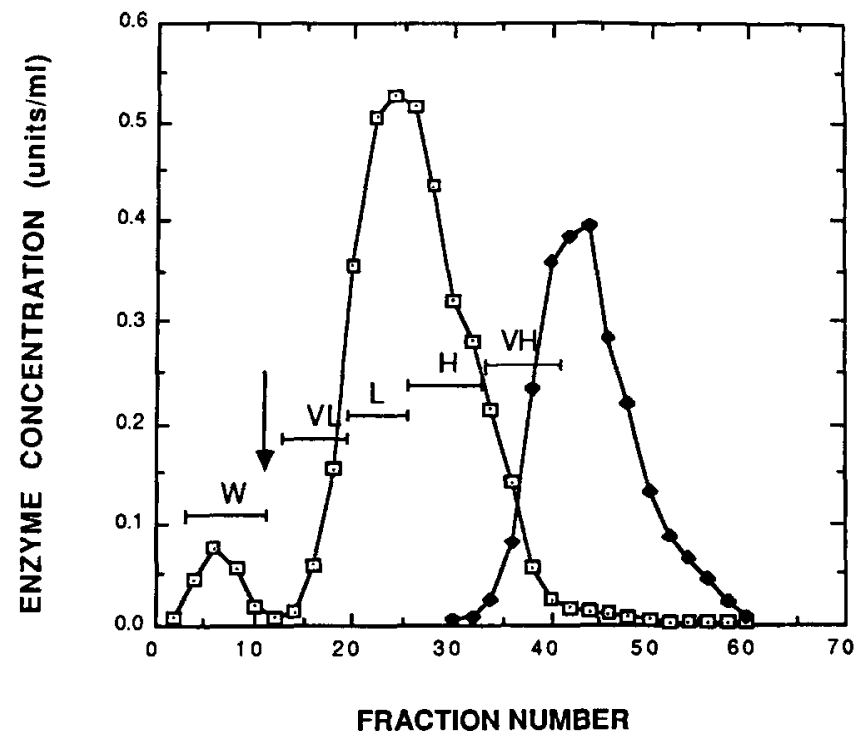

FIG. 1. Chromatography of $\beta$-galactosidase on DEAE-Sephacel. Affinity purified $\beta$-galactosidase (100 units) was applied to a $2 \times 15$ $\mathrm{cm}$ column DEAE-Sephacel as described under Materials and Methods. The column was washed with $0.05 \mathrm{M}$ Tris- $\mathrm{HCl}, \mathrm{pH} 7.5$, and eluted with a linear gradient of $\mathrm{NaCl}$ (from 0.0 to $0.2 \mathrm{M}$ ) beginning at the arrow. Fractions of $12 \mathrm{ml}$ were collected and analyzed for $\beta$-galactosidase $(\square)$ and $\beta-N$-acetylhexosaminidase ( $\square$ ). The fractions were pooled as indicated by the bars: $W$, column wash; VL, very low binding; $\mathrm{L}$, low binding; $\mathrm{H}$, high binding; and $\mathrm{VH}$, very high binding $\beta$ galactosidase pools. The receptor binding characteristics of the pooled fractions are described in Table 1.

$\beta$-galactosidase fractions by human generalized gangliosidosis skin fibroblasts (13) mimicked the phosphomannosyl receptor binding spectrum. The $K_{\text {uptake }}$ value determined for fraction $H(16.3$ munit/ml) suggests that a higher affinity PMR-1-like receptor may be primarily involved in the uptake process.

Inspection of each binding pool by SDS-PAGE run under reducing conditions revealed the presence of diffuse bands whose apparent molecular weights increased on elution from DEAE (Fig. 2). The calculated average molecular weights of the pooled fractions ranged from $62 \mathrm{kDa}$ (pool W) to $66 \mathrm{kDa}$ (pool VH). Pool VH, which represents only a small portion of the $\beta$-galactosidase, frequently showed other trace protein bands and contained measurable $\beta-N$-acetylhexosaminidase activity. It was separated to remove these contaminants.

Isoelectric focusing of the pooled fractions indicated multiple isoenzymes that differed in net charge (Fig. 3). As anticipated, the more basic constituents were eluted early from DEAE-Sephacel followed by more acidic elements in the higher binding fractions. Prior treatment of the high binding $\beta$-galactosidase pool $(\mathrm{H})$ with neuraminidase and/or alkaline phosphatase showed that this fraction contained phosphate, presumably mannose 6phosphate, and sialic acid (Fig. 4).

The carbohydrate content of each fraction is presented in Table 2. The more anionic, higher binding 
TABLE 1

Binding of $\beta$-Galactosidase Fractions to Phosphomannosyl Receptors and Uptake by Skin Fibroblasts

\begin{tabular}{ccccc}
\hline $\begin{array}{c}\text { Pooled } \\
\text { fraction }\end{array}$ & $\begin{array}{c}\text { Specific enzyme } \\
\text { activity } \\
\text { (units/mg protein) }\end{array}$ & $\begin{array}{c}\beta \text {-Galactosidase } \\
\text { bound to PMR-1 } \\
(\mu \text { unit/well) }\end{array}$ & $\begin{array}{c}\beta \text {-Galactosidase } \\
\text { bound to PMR-2 } \\
(\mu \text { unit/well) }\end{array}$ & $\begin{array}{c}\text { Uptake by fibroblasts }{ }^{c} \\
\text { (units/mg cell protein) }\end{array}$ \\
\hline W & 7.87 & 5.2 & 7.4 & 0.22 \\
VL & 8.03 & 9.3 & 10.2 & 0.37 \\
L & 7.98 & 15.8 & 27.5 & 0.66 \\
H & 8.25 & 22.3 & 37.5 & 0.82 \\
VH & 7.50 & 25.9 & 43.2 & 1.11 \\
\hline
\end{tabular}

Note. Equal concentrations of pooled fractions of $\beta$-galactosidase were exposed to PMR-1 and PMR-2 immobilized in multiwell plates. After incubation at $25^{\circ} \mathrm{C}$ for $2 \mathrm{~h}$, the plates were rapidly rinsed and the $\beta$-galactosidase content present in each well was determined. Values were corrected for nonspecific binding (14). Uptake of the pooled fractions by generalized gangliosidosis skin fibroblasts was performed as previously described (13). Both binding and uptake studies were performed with the subsaturating concentrations of $\beta$-galactosidase indicated in the footnotes.

${ }^{a} \beta$-Galactosidase (20 munit/125 $\mu$ l) was applied to each well; $0.4 \mu \mathrm{g}$ PMR-1 was immobilized in each well (14).

${ }^{b} \beta$-Galactosidase (20 munit/125 $\mu$ ) was applied to each well; $0.2 \mu \mathrm{g}$ PMR-2 was immobilized in each well (14).

${ }^{c} \beta$-Galactosidase ( 25 munit $/ 1.5 \mathrm{ml}$ culture medium) was applied to confluent fibroblasts in 35 -mm petri dishes (approximately $2 \times 10^{6}$ cells). After $3 \mathrm{~h}$ of exposure the cells were scraped from the plates, dispersed, and washed in saline. Enzyme activity was determined after disruption by freezing and thawing (13). Cell protein was determined by the procedure of Lowry (15).

pools contained higher levels of sialic acid and mannose 6-phosphate and moderately higher levels of mannose, galactose, and glucosamine than the lower binding fractions. The carbohydrate content of pool $\mathrm{H}$ approximated an expected analysis for an average content of one complex and one biantennary high mannose oligosaccharide chain per molecule. Removal of $\mathrm{N}$-glycosylated oligosaccharides from each fraction with $N$-glycanase and subsequent analysis on SDS-PAGE gels yielded a single major protein staining band from each fraction with an apparent molecular weight of $55.8 \mathrm{kDa}$ (data not shown). These data indicate that heterogeneity of the fractions is due to differences in the oligosaccharide chains which

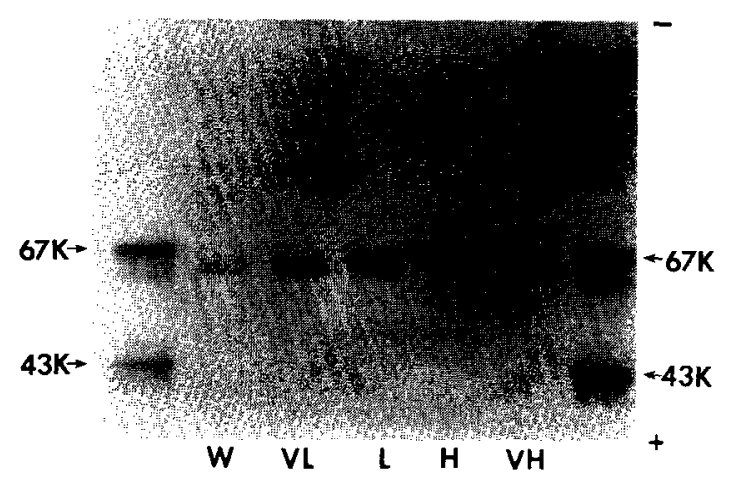

FIG. 2. SDS-polyacrylamide gel electrophoresis of pooled $\beta$-galactosidase fractions. Aliquots of the pooled fractions (10-50 $\mu \mathrm{g}$ protein) were subjected to electrophoresis and stained with Coomassie blue. Molecular weight markers for bovine serum albumin, $67 \mathrm{~K}$, and ovalbumin, $43 \mathrm{~K}$, are shown. To emphasize the size differences in the binding pools, only a portion of the gel is shown. Estimated average molecular weights of the pooled fractions are $62.1,62.8,63.7,64.7$, and 65.8 for pools $\mathrm{W}, \mathrm{VL}, \mathrm{L}, \mathrm{H}$, and $\mathrm{VH}$, respectively. are attached to a common polypeptide core. This finding is supported by the similar amino acid content of each of the pooled fractions (Table 3 ).

\section{DISCUSSION}

The modified procedure described for the purification of bovine testicular $\beta$-galactosidase allows removal of $\beta$-hexosaminidase that formerly contaminated affinitypurified $\beta$-galactosidase (1). Additionally, traces of catalytically active neuraminidase reported by others to associate with $\beta$-galactosidase through the affinity chromatography procedure (7) were also removed. After frac-

\section{pH $6.5 \rightarrow$}

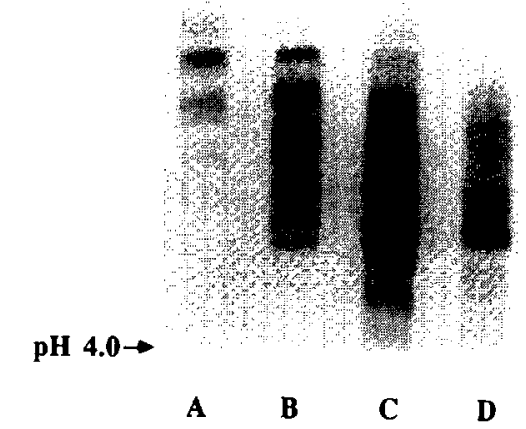

FIG. 3. Isoelectric focusing of $\beta$-galactosidase-pooled fractions. Aliquots ( 0.016 unit of $\beta$-galactosidase) were applied to gels prefocused with a $\mathrm{pH}$ gradient from 4 to 6.5 and developed as described under Materials and Methods. (A) $\beta$-Galactosidase pool VL; (B) pool L; (C) pool $\mathrm{H}$; and (D) pool VH. The gels were stained for $\beta$-galactosidase activity by the procedure of Lake (11). 


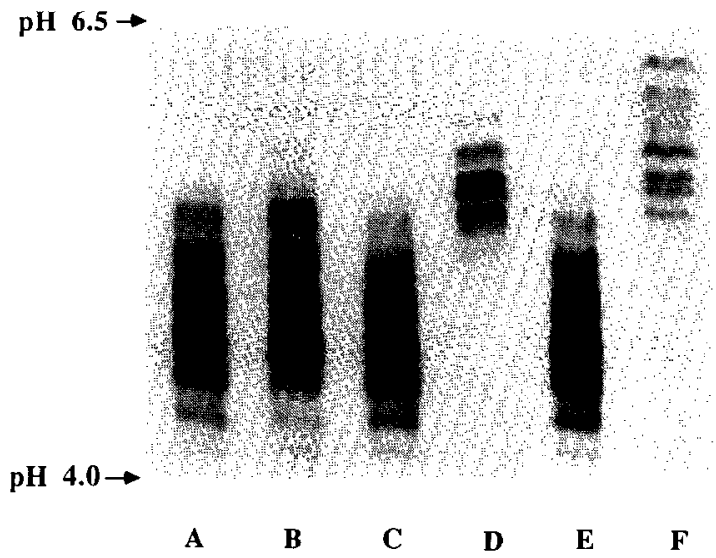

FIG. 4. Isoelectric focusing of $\beta$-galactosidase pool $\mathrm{H}$, before and after treatment, with alkaline phosphatase and/or neuraminidase. Aliquots ( 1.6 units $\beta$-galactosidase fraction $\mathrm{H}$ ) were treated with 1.0 unit $E$. coli alkaline phosphatase at $\mathrm{pH} 7.5$ or 0.2 unit Clostridium perfringens neuraminidase in $0.05 \mathrm{M}$ sodium acetate buffer ( $\mathrm{pH} 5.0$ ) at $37^{\circ} \mathrm{C}$ for $24 \mathrm{~h}$. Isoelectric focusing was performed as described in Fig. 3. (A) $\beta$-Galactosidase pool $\mathrm{H}$; (B) pool $\mathrm{H}$ after treatment with alkaline phosphatase; (C) pool $\mathrm{H}$; (D) pool $\mathrm{H}$ after treatment with neuraminidase; (E) pool $\mathrm{H}$; and (F) pool $\mathrm{H}$ after treatment with alkaline phosphatase followed by neuraminidase.

tionation of the enzyme on DEAE-Sephacel, pools of enzyme were obtained that exhibited differing capacity for assimilation of the enzyme by cultured cells as well as binding to both low and high molecular weight phosphomannosyl receptors. The higher binding, higher assimilation pools of the enzyme showed higher average molecular weights, increased carbohydrate content, and more acidic isoenzymes than the lower binding pools. The anionic nature of the high binding fractions was shown to be due to the presence of both sialic acid and mannose 6-phosphate residues. The carbohydrate content of high binding fraction $(\mathrm{H})$ closely approximated the expected values calculated for one completely sialylated complex oligosaccharide and one high mannose oligosaccharide bearing two to three mannose 6-phosphate residues. The

TABLE 2

Carbohydrate Composition of Pooled $\beta$-Galactosidase Fractions

\begin{tabular}{lrrrr}
\hline & \multicolumn{4}{c}{$\beta$-Galactosidase fractions } \\
\cline { 2 - 5 } & VL & L & H & VH \\
\cline { 3 - 5 } \multicolumn{1}{c}{ Carbohydrate } & \multicolumn{4}{c}{ (nmol/mg protein) } \\
\hline Glucosamine & 136 & 117 & 124 & 151 \\
Mannose & 136 & 167 & 214 & 279 \\
Galactose & 38 & 35 & 54 & 90 \\
N-Acetylsiglic acid & 12 & 21 & 58 & 84 \\
Mannose 6-phosphate & 7 & 15 & 20 & 28 \\
\hline
\end{tabular}

TABLE 3

Amino Acid Composition of Pooled $\beta$-Galactosidase Fractions

\begin{tabular}{|c|c|c|c|c|}
\hline \multirow[b]{2}{*}{$\begin{array}{l}\text { Amino acid } \\
\text { residues }\end{array}$} & \multicolumn{4}{|c|}{$\beta$-Galactosidase fractions } \\
\hline & \multicolumn{4}{|c|}{ (residues/1000) } \\
\hline Aspartic acid & 105 & 105 & 105 & 104 \\
\hline Threonine & 56 & 58 & 60 & 58 \\
\hline Serine & 48 & 51 & 56 & 53 \\
\hline Glutamic acid & 92 & 90 & 90 & 91 \\
\hline Proline & 70 & 70 & 70 & 70 \\
\hline Glycine & 83 & 80 & 80 & 89 \\
\hline Alanine & 59 & 59 & 60 & 58 \\
\hline Half-cystine & 8 & 9 & 9 & 7 \\
\hline Valine & 70 & 70 & 70 & 71 \\
\hline Methionine & 19 & 21 & 21 & 19 \\
\hline Isoleucine & 46 & 43 & 44 & 41 \\
\hline Leucine & 123 & 122 & 118 & 118 \\
\hline Tyrosine & 51 & 50 & 49 & 50 \\
\hline Phenylalanine & 59 & 59 & 56 & 58 \\
\hline Lysine & 45 & 46 & 49 & 44 \\
\hline Histidine & 22 & 23 & 22 & 22 \\
\hline Arginine & 46 & 44 & 42 & 43 \\
\hline
\end{tabular}

oligosaccharides of the lower binding fractions contained significantly lower amounts of sialic acid and mannose 6-phosphate. Low binding fraction (L) was estimated to contain only an average of one mannose 6phosphate residue per molecule enzyme. It should be pointed out, however, that isoelectric focusing gels indicated that all the pooled fractions were heterogeneous with respect to charge, hence individual structures are difficult to define.

The lower carbohydrate content in some of the $\beta$-galactosidase fractions may be due to lysosomal degradation or alternatively incomplete processing or trimming. It has been established that the major portion of acid $\beta$ galactosidase extracted from testes arises from the lysosomes (17) and partial removal of phosphate has been noted following targeting of newly synthesized lysosomal enzymes into lysosomes (18). Therefore, the heterogeneity of the extracted enzyme may be at least in part attributed to differences in the cellular age of the individual enzyme molecules. These differences appear not to include major proteolytic cleavage since amino acid analyses of the fractions were similar and sharp SDS-PAGE bands were obtained following treatment with endoglycanase. Chromatography on DEAE-Sephacel partially separates the heterogeneously charged entities. The resulting high binding fraction of $\beta$-galactosidase is suitable for binding studies with both low and high molecular weight phosphomannosyl receptors. Additionally, either of the two major binding fractions ( $L$ and $\mathrm{H}$ ) are highly purified, high specific activity enzyme fractions that are suitable for removing $\beta$-galactosyl residues from a broad range of biological materials. 


\section{REFERENCES}

1. Distler, J. J., and Jourdian, G. W. (1973) J. Biol. Chem. 248, 6772-6780.

2. Distler, J. J., and Jourdian, G. W. (1978) in Methods in Enzymology (Ginsburg, V., Ed.), Vol. 50, pp. 514 520, Academic Press, San Diego, CA.

3. Distler, J., Hieber, V., Sahagian, G., Schmickel, R., and Jourdian, G. W. (1979) Proc. Natl. Acad. Sci. USA 76, 4235-4239.

4. Natowicz, M. R., Chi, M. M.-Y., Lowry, O. H., and Sly, W. S. (1979) Proc. Natl. Acad. Sci. USA 76, 4322-4326.

5. Sahagian, G. G., Distler, J., Jourdian, G. W. (1981) Proc. Natl. Acad. Sci. USA 78, 4289-4293.

6. Distler, J. J., and Jourdian, G. W. (1987) in Methods in Enzymology (Ginsburg, V., Ed.), Vol. 138, pp. 504-509, Academic Press, San Diego, CA.

7. van der Horst, G. T. J., Galjart, N. J., d'Azzo, A., Galjaard, H., and Verheijen, F. W. (1989) J. Biol. Chem. 264, 1317-1322.

8. Sahagian, G., Distler, J., Hieber, V., Schmickel, R., and Jourdian, G. W. (1979) Fed. Proc. 38, 467.
9. Sahagian, G. G., Distler, J. J., and Jourdian, G. W. (1982) in Methods in Enzymology (Ginsburg, V., Ed.), Vol. 83, pp. 392-396, Academic Press, San Diego, CA.

10. Laemmli, U. K. (1970) Nature (London) 227, 680-685.

11. Lake, B. D. (1974) Histochem. J. 6, 211-218.

12. Jourdian, G. W., and Distler, J. J. (1972) Carbohydr. Res. 22, 369379.

13. Hieber, V., Distler, J., Myerowitz, R., Schmickel, R. D., and Jourdian, G. W. (1980) J. Clin. Invest. 65, 879-884.

14. Distler, J. J., Patel, R., and Jourdian, G. W. (1987) Anal. Biochem. 166, $65-71$.

15. Lowry, O. H., Rosebrough, N. J., Farr, A. L., and Randall, R. J. (1951) J. Biol. Chem. 193, 265-275.

16. Cassidy, J. T., Jourdian, G. W., and Roseman, S. (1965) J. Biol. Chem. 240, 3501-3506.

17. Distler, J. J., and Jourdian, G. W. (1977) Arch. Biochem. Biophys. 178, 631-643.

18. Gabel, C. A., Goldberg, D. E., and Kornfeld, S. (1982) J. Cell Biol. 95, 536-542. 